\title{
On the presence of the family Torrenticolidae Piersig (Acari, Hydrachnidia) in interstitial waters of Sicily (South Italy) : description of a new species
}

\author{
A. Di Sabatino 1 \\ B. Cicolani1
}

Keywords : interstitial waters, water mites, Torrenticolidae, new species, Sicily.

Eleven species of the water mite family Torrenticolidae Piersig are reported from interstitial waters of Sicily. The male, female and deutonymph of Torrenticola hyporheica n.sp. are described. The morphological traits of the new species suggest adaptation to life in groundwaters and indicate affinities with other hyporheobiont species of the genus such as $T$. ramigera Szalay and $T$. jeanneli Motas \& Orghidan. The high number of Torrenticolid-species found in interstitial habitats may be related to the adaptive morphological features of members of this family and more directly to hydrogeological conditions on the island. Torrenticola lativalvata, Torrenticola hyporheica and Torrenticola trinacriae were the most abundant species collected. Marked differences between the distributions of species of the family in Sicily and Corsica are pointed out.

Sur la présence de Torrenticolidae Piersig (Acari, Hydrachnidia) dans les eaux interstitielles de Sicile (Italie) : description d'une nouvelle espèce

Mots clés : eaux interstitielles, hydracariens, Torrenticolidae, nouvelle espèce, Sicile.

Onze espèces d'hydracariens appartenant à la famille des Torrenticolidae Piersig ont été recueillies dans les eaux interstitielles de Sicile. Le mâle, la femelle et la deutonymphe de Torrenticola hyporheica $n$.sp. sont décrits. La morphologie de cette espèce semble bien adaptée à la vie dans le milieu hyporhéique comme cela a déjà été observé chez deux autres espèces hyporhéobiontes du même genre ( $T$. ramigera et $T$. jeanneli $)$. Les caractéristiques morphologiques adaptatives de la famille et les conditions hydrogéologiques de l'île justifient le nombre élevé d'espèces recueillies. T. lativalvata, $T$. hyporheica et $T$. trinacriae sont les espèces les plus abondantes.

Des différences notables ont été mises en évidence entre la distribution des espèces de cette famille en Corse et en Sicile.

\section{Introduction}

The distribution of water mites in Italian ground waters is poorly known. To date, only a few papers have addressed this topic (Schwoerbel 1961, 1962a, Bader 1983, Teschner 1988, Viets 1939), Gerecke (1991) recently investigated the water mite fauna of superficial and subterranean habitats in southern Italy. Some of these results are summarized here. In particular, we refer to the presence of the genera Torrenticola Piersig and Pseudotorrenticola Walter, in interstitial waters of Sicily. For the general distribution of mites of the family Torrenticolidae in Sicily and in the Mediterranean region, see the

1. Dipartimento di Scienze Ambientali, University of L'Aquila. Via Vetoio 20 Coppito, 67100 L'Aquila, Italy.

12 th contribution to the knowledge of the water mites of the Apennines. detailed catalogue in Di Sabatino et al. 1992. Faunistic, taxonomic and ecological informations on many of the species included in this study, are reported in Di Sabatino \& Cicolani $(1989,1990,1992)$, Di Sabatino et al. (1992) and Cicolani \& Di Sabatino (1990).

\section{Methods}

Samples were taken using the Karaman-Chappuis method (Delamare Deboutteville 1960) : small holes $(25$ to $50 \mathrm{~cm}$. deep) were dug near water courses and, during periods of drought, characteristic of Sicilian running waters, similar samples were also taken directly from river beds. Water mites were separated from other fauna and preserved in Koenike fluid. Specimens were mounted in Faure medium for identification. All the material was collected by $\mathbf{R}$. Gerecke. 


\section{Study Area}

The investigated habitats were located in various mountain ranges throughout the island (Table 1). Fig. 1 : illustrates the locations of sampling stations and indicates those samples in which water mites were found. For a complete description of the study area see Gerecke (1991) and Di Sabatino et al. (1992). A complete list of water mite species collected is also reported by Gerecke (1991).

\section{Species collected}

\section{Genus Torrenticola Piersig 1896}

Torrenticola andrei (Angelier 1950).
Stations : Nebrodi 569I ( 2 males/0 females/0 nymphs). 1138I (1/1/0); Madonie 512I (1/0/0).

The species, typical of interstitial waters (Schwoerbel 1986), was represented by few individuals ; it is also present in the epigean waters of the island (Di Sabatino et al. 1992). The species seems confined to groundwaters in the northernmost part of its distribution while in the Mediterranean area it is regularly distributed in superficial waters (Lundbland 1956, Angelier 1954).

Torrenticola anomala (Koch 1837)

Stations : Iblei 543I (1/0/0), 544I (0/1/0).

Only two individuals of this species were collected in the area of Iblei Mountains.

Table 1 . Sicily : list of interstitial sample-sites. $(F=$ river $; T=$ stream ; F.ra $=$ " Fiumara »).

Tableau 1. Sicile : liste des stations interstitielles prospectées : $(F=$ rivière $; T=$ cours d'eau ; F.ra $=$ petit cours d'eau).

\begin{tabular}{|c|c|c|c|c|c|c|}
\hline $\begin{array}{c}\text { site } \\
n^{\circ}\end{array}$ & watercourse & locality & Prov. & date & $\begin{array}{c}\text { Alt. } \\
\text { m. asl }\end{array}$ & $\begin{array}{c}\text { Conduc. } \\
\mathrm{ms} / \mathrm{cm}\end{array}$ \\
\hline \multicolumn{7}{|c|}{ PELORITANI MOUNTAINS } \\
\hline $573 I$ & F.ra di FLORESTA & S.Lucia & $(M E)$ & $16 / 09 / 87$ & 660 & 0.51 \\
\hline $.576 I$ & F.ra di FRANCO & Itala & $(M E)$ & $20 / 09 / 87$ & 400 & 0.53 \\
\hline $591 I$ & T.FIUMEDINISI & P.Strumbo & $(M E)$ & $04 / 10 / 87$ & 420 & \\
\hline $593 I$ & T.FIUMEDINISI & Migliuso & (ME) & $04 / 10 / 87$ & 270 & 0.41 \\
\hline \multicolumn{7}{|c|}{ NEBRODI. MOUNTAINS } \\
\hline $569 I$ & F. CARONIA & T.Marchina & $(\mathrm{CT})$ & $11 / 09 / 87$ & 150 & 0.49 \\
\hline $1138 I$ & T. SARACENA & Chiusitta & $(M E)$ & $20 / 10 / 90$ & 1200 & - \\
\hline \multicolumn{7}{|c|}{ MADONIE MOUNTAINS } \\
\hline $510 I$ & F. POLLINA & Buonanotte & $(\mathrm{PA})$ & $-14 / 10 / 86$ & 50 & 0.95 \\
\hline $511 \mathrm{I}$ & T. in V.MULINI & Castelbuono & $(\mathrm{PA})$ & $14 / 10 / 86$ & 350 & $0.78^{\circ}$ \\
\hline $512 I$ & T.VICARETTO & Castelbuono & $(\mathrm{PA})$ & $14 / 10 / 86$ & 320 & 0.48 \\
\hline \multicolumn{7}{|c|}{ SICANI MOUNTAINS } \\
\hline $472 \mathrm{I}$ & F.SOSIO & S.Carlo & $(P A)$ & $25 / 08 / 86$ & 200 & 0.63 \\
\hline $473 I$ & F. VERDURA & Calamonaci & $(A G)$ & $25 / 08 / 86$ & 95 & 0.99 \\
\hline \multicolumn{7}{|c|}{ IBLEI MOUNTAINS } \\
\hline $534 I$ & F.MANGHISI & Noto & $(S R)$ & $11 / 11 / 86$ & 390 & 0.46 \\
\hline $543 I$ & F.ANAPO & Cassaro & $(S R)$ & $01 / 12 / 86$ & 360 & 0.66 \\
\hline $544 \mathrm{I}$ & F.MANGHISI & M. Papa & $(\mathrm{SR})$ & $01 / 12 / 86$ & 390 & 0.49 \\
\hline $551 I$ & T.S.CHIARA & Noto & $(\mathrm{SR})$ & $30 / 08 / 87$ & 300 & 0.45 \\
\hline $552 I$ & F.ra GRANDE & Sortino & $(\mathrm{SR})$ & $30 / 08 / 87$ & 450 & 0.43 \\
\hline $553 I$ & F.ra GRANDE & C. Carubba & $(S R)$ & $30 / 08 / 87$ & 320 & 0.32 \\
\hline \multicolumn{7}{|c|}{ NW-MOUNTAINS } \\
\hline $493 I$ & T.BATTICANO & Corleone & $(P A)$ & $11 / 09 / 86$ & 375 & $0: 73$ \\
\hline
\end{tabular}




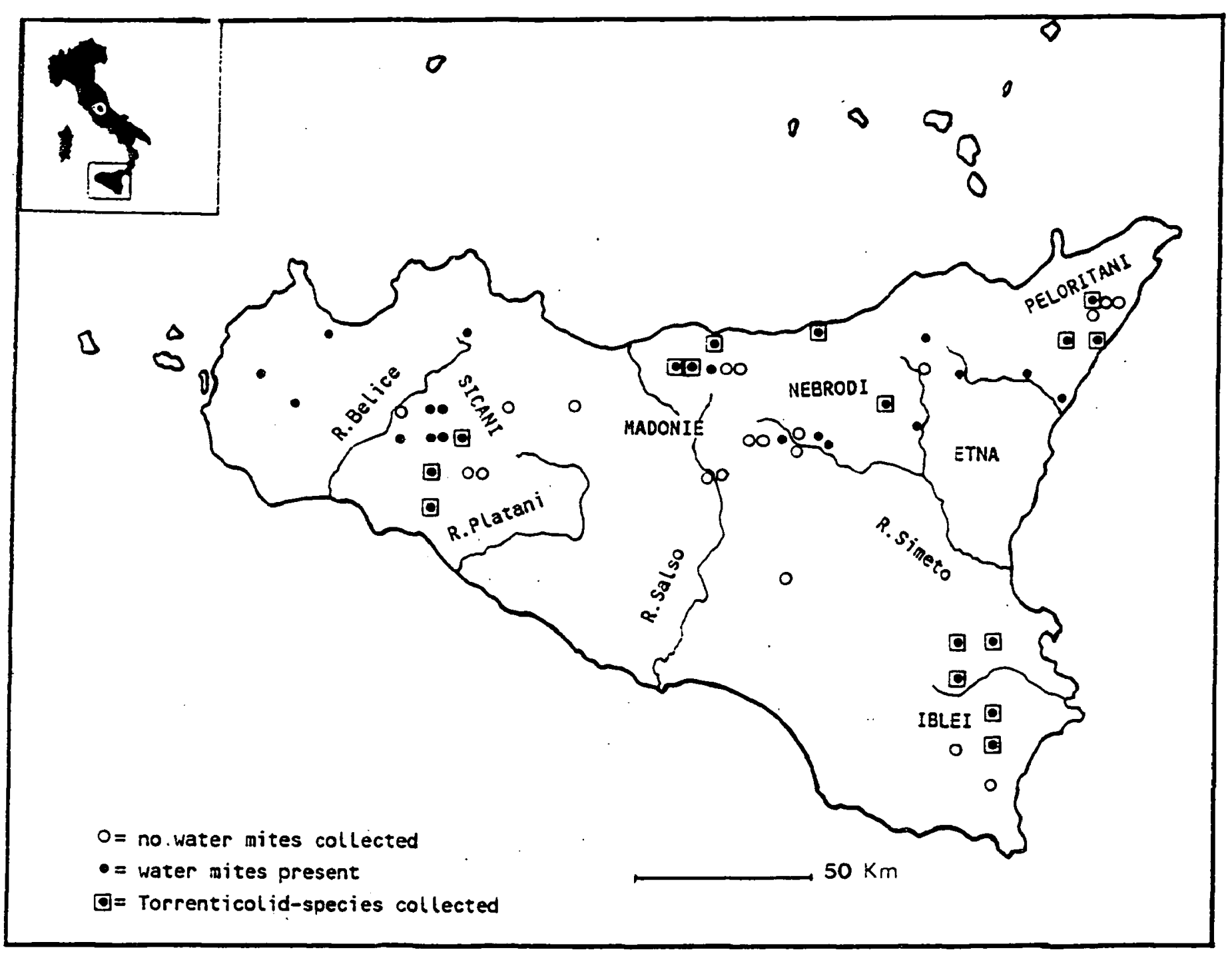

Fig. 1. Study area and distribution of the collecting sites.

Fig. 1. Région étudiée et emplacement des statiōns prospectées.

Torrenticola barsica (Szalay 1933)

Stations : Nebrodi 5691 (1/2/0) ; Peloritani 591I $(0 / 1 / 0)$; Iblei 544I $(0 / 1 / 0)$; NW-Mountains $493 \mathrm{I}$ $(0 / 1 / 0)$.

Members of this surface-living species were occasionally collected in hyporheic habitats.

Torrenticola brevirostris (Halbert 1911)

Stations : Madonie 511 I (0/3/0).

The presence of this species in interstitial habitats was probably accidental.

\section{Torrenticola hyporheica n.sp.}

Material : Peloritani 573I (7/2/0), 574I (1/0/0), 576I (3/1/2), Nebrodi 1138I (1/1/0); Madonie 511I $(0 / 1 / 0)$; Sicani $473 I(0 / 1 / 0)$.

Locus typicus : site $\mathrm{n}^{\circ}$ 573I, Peloritani Mts., fiumara di Floresta in locality S. Lucia (ME), UTM : WC $2009,450 \mathrm{~m}$. asl, temperature $19.9^{\circ} \mathrm{C}$, conduc- tivity of interstitial water $0.63 \mathrm{mS} / \mathrm{cm} ; 16 / 09 / 87$. Types and paratypes are in the author's collection (L'Aquila) and the collection of R. Gerecke (München).

\section{Description :}

- Holotype, Male (prep. 701) from locus typicus. Dorsum (Fig. 2a) with dorsal shield, $570 \mu \mathrm{m}$ long and $400 \mu \mathrm{m}$ wide, composed of a large plate with two pairs of small platelets on the anterior margin. Length of anterior platelet $117 \mu \mathrm{m}$, posterior platelet $172 \mu \mathrm{m}$. Ocular pigment extremely reduced. Venter (Fig. 2b) with capitular bay $129 \mu \mathrm{m}$ deep and $98 \mu \mathrm{m}$ wide ; ventral length of body $665 \mu \mathrm{m}$, ventral width $446 \mu \mathrm{m}$. Total length of first coxal plates $274 \mu \mathrm{m}$, medial length of coxae II + III $90 \mu \mathrm{m}$; genital field round, $129 \mu \mathrm{m}$ long and $105 \mu \mathrm{m}$ wide. Suture lines of fourth coxae extending posteriorly beyond genital field and strongly curved. Distance 
a
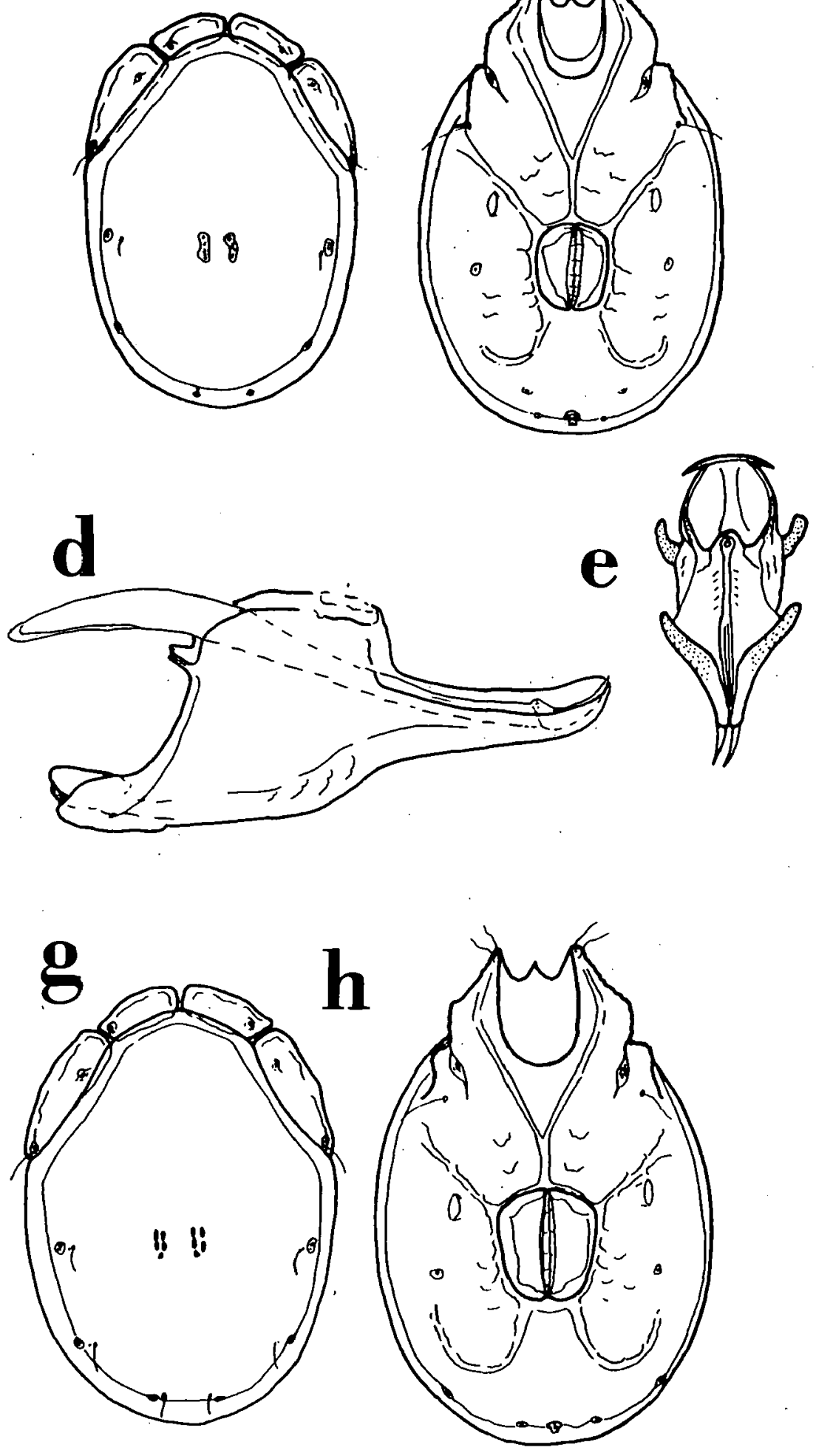

i

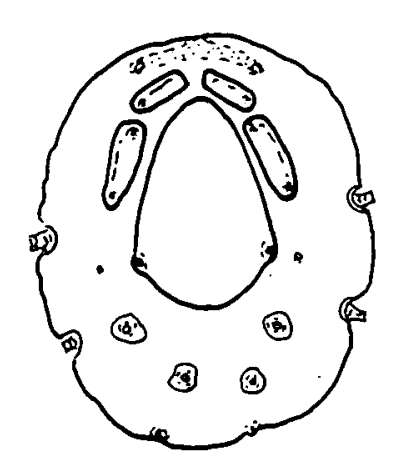

b
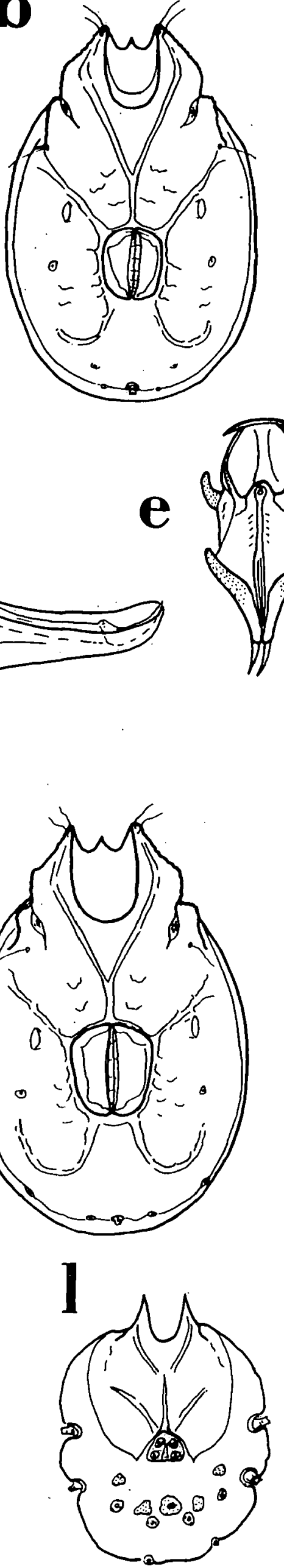
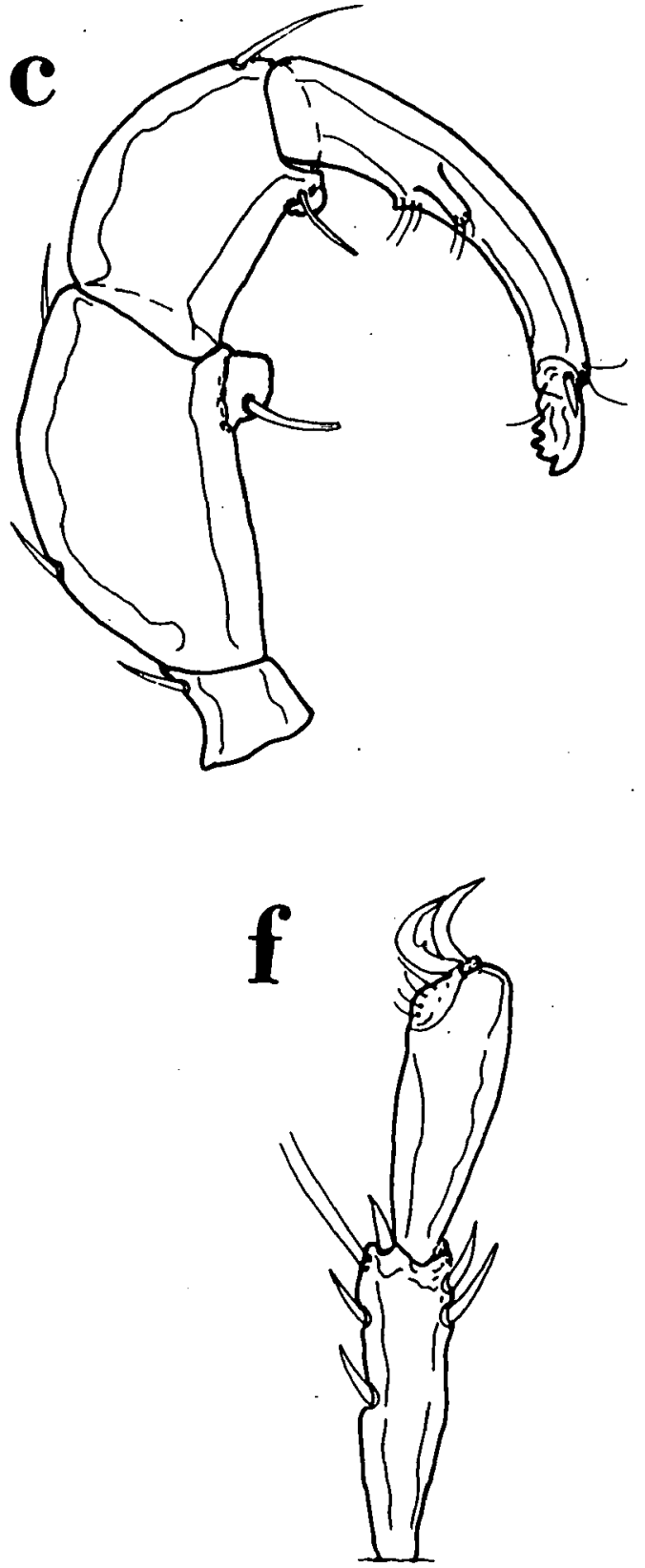

a.b.g.h.i.l $300 \mu \mathrm{m}$ d. e.f $100 \mu \mathrm{m}$
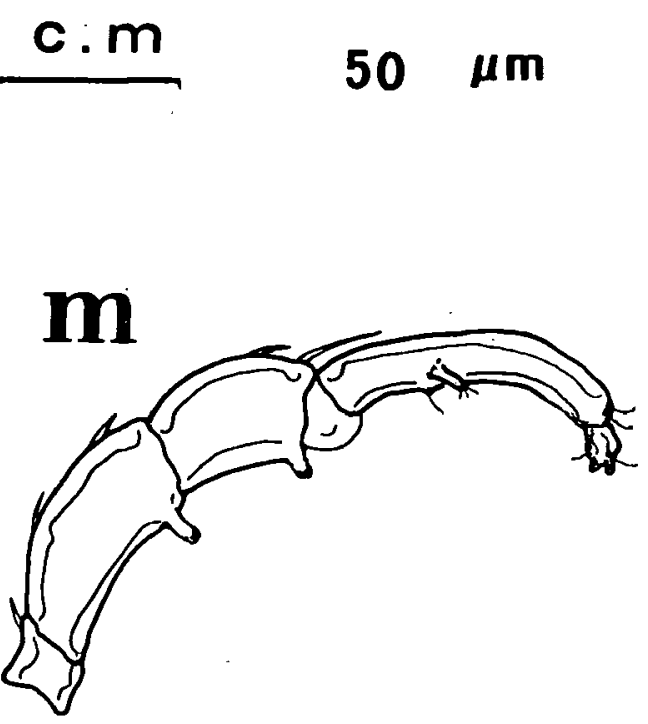

Fig. 2. Torrenticola hyporheica $\mathrm{n} . \mathrm{sp}$. (a-f male; $\mathrm{g}, \mathrm{h}$ female; $\mathrm{i}-\mathrm{m}$ deutonymph) : a, g, $\mathrm{i}=$ dorsal view ; b $\mathrm{h}, \mathrm{l}=$ ventral view ; $c, m=$ palps $; d=$ infracapitulum ; $e=$ ejaculatory complex $; f=I V-L e g-5$ and 6.

Fig. 2. Torrenticola hyporheica $\mathrm{n} . \mathrm{sp}$. (a-f mâle; $\mathrm{g}, \mathrm{h}$ femelle; $\mathrm{i}-\mathrm{m}$ deutonymphe) $: \mathrm{a}, \mathrm{g}, \mathrm{i}=$ vue dorsale ; b, h, $\mathrm{l}=$ vue ventrale ; $c, m=$ palpes $; d=$ infracapitulum $; e=$ organe éjaculateur $; f=$ patte IV - articles 5 et 6. 
from posterior margin of genital field to excretory pore $150 \mu \mathrm{m}$, to posterior edge of ventral shield 167 $\mu \mathrm{m}$.

Gnathosoma with infracapitulum (Fig. 2d) $335 \mu \mathrm{m}$ long and $119 \mu \mathrm{m}$ high ; chelicera $356 \mu \mathrm{m}$ long with a short terminal claw. Palp as in fig. $2 \mathrm{c}$ with dimen- sions as in Table 2. Ventral projection of P-II and P-III characteristic. P-IV with an accessory medial tubercle bearing three terminal short hairs.

Legs with measurements as in Table 2 . Two short hairs inserted on distal margin of III and IV-Leg-5 (Fig. 2f).

Table 2. Leg and palp measurements (in $\mu \mathrm{m}$ ) of male and female of T. hyporheica $\mathrm{n} . \mathrm{sp}$.

Tableau 2. Longueurs des pattes et des palpes (en $\mu \mathrm{m}$ ) des $O^{\prime \prime}$ et ${ }_{T}$ de T. hyporheica n.sp.

\begin{tabular}{lccccccccccccr}
\hline & \multicolumn{4}{c}{ MALE } & \multicolumn{1}{c}{ FEMALE } \\
\hline $\begin{array}{l}\text { Segments } \\
\text { L e g s }\end{array}$ & 1 & 2 & 3 & 4 & 5 & 6 & 1 & 2 & 3 & 4 & 5 & 6 \\
\hline I & 35 & 55 & 70 & 85 & 100 & 80 & 29 & 65 & 74 & 90 & 102 & 92 \\
II & 36 & 57 & 71 & 86 & 109 & 104 & 32 & 68 & 75 & 90 & 109 & 102 \\
III & 36 & 66 & 71 & 93 & 111 & 107 & & 32 & 70 & 78 & 98 & 117 & 110 \\
IV & 102 & 80 & 95 & 119 & 142 & 130 & 102 & 78 & 102 & 137 & 149 & 127 \\
\hline Palps & P-I & P-II & P-III & P-IV & P-V & P-I & P-II & P-III & P-IV & P-V \\
& 30 & 107 & 83 & 128 & 23 & & 37 & 116 & 90 & 130 & 26 \\
\hline
\end{tabular}

Ejaculatory complex (Fig. 2e) typical of the genus (Cicolani \& Di Sabatino 1990), total length (excluding apical setae) $160 \mu \mathrm{m}$, diameter of proximal chamber $57 \mu \mathrm{m}$. Proximal horns and anterior keel well developed, proximal and distal arms strongly sclerotized.

\section{- Female (paratype $\mathrm{n}^{\circ} 702$ from locus typicus).}

Dorsum (Fig. 2g) : dorsal shield $655 \mu \mathrm{m}$ long and $437 \mu \mathrm{m}$ wide, length of anterior platelet $125 \mu \mathrm{m}$, posterior $207 \mu \mathrm{m}$. Ocular pigment almost absent. Venter (Fig. 2h) : total length $731 \mu \mathrm{m}$, maximal width $590 \mu \mathrm{m}$; capitular bay $137 \mu \mathrm{m}$ deep and 104 $\mu \mathrm{m}$ wide. Length of first coxal plates $278 \mu \mathrm{m}$, coxae II + III $70 \mu \mathrm{m}$; genital field pentagonal in shape, $164 \mu \mathrm{m}$ long and $141 \mu \mathrm{m}$ wide. Suture lines of fourth coxae more pronounced than in male. Distance from posterior margin of genital field to excretory pore $188 \mu \mathrm{m}, 204 \mu \mathrm{m}$ to posterior edge of body. Individual ovigerous with two eggs $150 \mu \mathrm{m}$ in diameter. Gnathosoma with infracapitulum as in male, $374 \mu \mathrm{m}$ long and $133 \mu \mathrm{m}$ high, rostrum extending $145 \mu \mathrm{m}$ from insertions of palps, chelicera $390 \mu \mathrm{m}$ long. Morphology and chaetotaxy of palps as in male, with dimensions as in Table 2.

Legs : morphology and chaetotaxy as in male, measurements given in Table 2 .

\section{- Deutonymph (from Station 576I)}

Body soft and round, $380 \mu \mathrm{m}$ in length and $313 \mu \mathrm{m}$ in width.

Dorsum (Fig. 2i) with dorsal plate $205 \mu \mathrm{m}$ long and $152 \mu \mathrm{m}$ maximal width and two pairs of small platelets of which anterior is $55 \mu \mathrm{m}$ long and posterior $98 \mu \mathrm{m}$.

Venter (Fig. 21). Capitular bay $78 \mu \mathrm{m}$ long and 66 $\mu \mathrm{m}$ wide, coxal plates $260 \mu \mathrm{m}$ in length, suture line of coxae II + III not completely fused medially, 65 $\mu \mathrm{m}$ long. Provisional genital field $45 \mu \mathrm{m}$ long and $52 \mu \mathrm{m}$ wide, with two pairs of genital acetabula.

Palps (Fig. $2 \mathrm{~m}$ ) : P-II and P-III slender, bearing well developed and toothed ventral projections, P-IV with characteristic medial tubercle. Dorsal lengths of segments as follows : P-I $14 \mu \mathrm{m}$, P-II $62 \mu \mathrm{m}$, P-III $48 \mu \mathrm{m}, \mathrm{P}-I V 72 \mu \mathrm{m}$ and P-V $14 \mu \mathrm{m}$.

\section{Remarks}

The characteristic medial tubercle on P-IV is also found in two other hyporheobiont species of Torrenticola, $T$. jeanneli Motas and Orghidan and $T$. ramigera Szalay. The shape of the ventral projecion on P-II and P-III appears to represent a synapomorphy shared with $T$. ramigera. These two species are compared in Table 3 on the basis of morphological indices previously used to discriminate Italian species of the genus (Cicolani \& Di Sabatino 1990). 
Table 3. Comparison of morphological indices between $T$. hyporheica $\mathrm{n} . \mathrm{sp}$. and $T$. ramigera. $(\mathrm{A}=$ ratio width/length of dorsal shield ; B = ratio medial length coxae II + III/total length coxae I ; C $=$ ratio width/length of genital field $; \mathrm{D}=\mathrm{ratio}$ dorsal length P-II/P-IV ; E = ratio distance genital field terminal end of body/ventral length. All indices expressed as percentages).

Tableau 3. Comparaison des indices morphologiques de $T$. hyporheica n.sp. et $T$. ramigera. $(\mathrm{A}=$ rapport largeur/longueur du bouclier dorsal ; B = rapport largeur/longueur du champ génital ; D = rapport longueur dorsale P-IL/P-IV ; E = rapport de la distance du champ génital à l'extrémité terminale du corps/longueur ventrale. Tous les indices sont exprimés en pourcentages).

\begin{tabular}{|c|c|c|c|c|c|}
\hline \multirow{2}{*}{$\begin{array}{l}\text { Morph. } \\
\text { indices }\end{array}$} & \multicolumn{2}{|c|}{ T. hyporheica } & \multicolumn{3}{|c|}{ T. ramigera } \\
\hline & $\sigma^{\prime \prime}$ & Q & $\begin{array}{c}\stackrel{9}{\text { Szalay, } 1947}\end{array}$ & $\begin{array}{c}O^{\prime \prime} \\
\text { Ange }\end{array}$ & $\begin{array}{c}\stackrel{9}{9} \\
1950\end{array}$ \\
\hline $\mathbf{A}$ & 70.1 & 66.7 & 61.7 & 63.2 & 61.2 \\
\hline B & 32.8 & 25.1 & 24.9 & 19.5 & 13.1 \\
\hline C & 81.4 & 85.9 & 83.8 & 80.3 & 82.4 \\
\hline D & 83.5 & 89.2 & 88.6 & 96.5 & - \\
\hline E & 25.1 & 22.8 & 35.1 & 27.9 & 31.2 \\
\hline
\end{tabular}

Based on measurements of $T$. ramigera reported by Szalay (1947), they appear to differ in the length and width of the body (index A), the lengths of the palpal segments and the size of the postgenital area (index E). These differences seem to be confirmed by the measurements of $T$. ramigera given by Angelier (1950) in the original description of the male (Table 3 ). It should be noted that slidemounted specimens from Corsica in the Viets collection, labelled as «T. ramigera -S.M.F. 8016- Angelier 2195 » exhibit a different and unique morphology of the ventral projection on P-II and P-III. Moreover, the medial tubercle on P-IV is located anterior to the ventral tubercle. These differences suggest that the specimens described by Angelier may belong to another species which seems more similar to $T$. jeanneli than $T$. ramigera.

The new species can be distinguished from $T$. ramigera by the extreme reduction of the ocular pigment, the less elongated bodyshape, the smaller post-genital area and the ventral projection on P-II being larger and in the form of a thin toothed lamina (Fig. 2c) rather than a cone.

\section{Torrenticola lativalvata Viets 1952}

Stations : Peloritani 593I (2/0/0). Sicani 472I $(0 / 1 / 3)$. 473I $(0 / 1 / 1)$. Iblei 534I $(6 / 4 / 0), 551$ I $(3 / 3 / 0), 552 \mathrm{I}(1 / 1 / 0), 553 \mathrm{I}(24 / 22 / 8)$.

It is the most abundant species in the superficial waters of Sicily (Di Sabatino et al. 1992). Adults are capable of migrating to the hyporheic habitat during periods of drought and strong reduction of flow. These conditions are particularly typical of habitats in the Iblei Mountains where 90 percent of the specimens of $\boldsymbol{T}$. lativalvata were collected.

Torrenticola cé lusitanica (Lundblad 1941)

Stations : Nebrodi 569I (1/0/1), Madonie 512I (1/0/0). Iblei 552I (0/1/0). NW-Mountains 493I (3/6/0).
The species inhabits superficial waters throughout the island, and occurs only occasionally in the hyporheic habitat.

\section{Torrenticola stadleri (Walter 1924)}

Stations : Nebrodi 11381 (0/0/1); Madonie 511I $(1 / 2 / 0)$.

The species was occasionally collected in two sites in Nebrodi and Madonie. Interestingly, in Corsica, it was one of the two Torrenticolid-species (with $T$. andret) found to be relatively abundant in interstitial waters (Angelier 1953).

Torrenticola trinacriae Di Sabatino \& Cicolani 1990 Stations : Peloritani 573I (1/0/0). Nebrodi 569I (1/1/0). Madonie 510I (2/0/1). Sicani 472I (1/0/1). Iblei 534I (0/1/0). NW-Mountains 493I (3/6/0).

The species was recently described from Sicily, and was collected in both superficial and interstitial waters throughout the island. The morphological features of $T$. trinacriae and its relative abundance in interstitial waters, seem to indicate that the species is hyporheophilic.

\section{Torrenticola ungeri (Szalay 1927)}

Stations : Peloritani 5931 (1/0/0).

Only one male of this hyporheobiontic species (Schwoerbel 1986) was found in hyporheic waters. On the contray, it was well distributed in superficial waters of the island. Both in Corsica (Angelier 1953, 1954). Spain (Lundblad 1956) and Southern Italy (Cicolani \& Di Sabatino 1990), T. ungeri appears to be mainly confined to superficial habitats. 
Genus Pseudotorrenticola Walter 1906

Pseudotorrenticola rhynchota Walter 1906

Stations : Iblei 534I $(0 / 1 / 0), 544 \mathrm{I}(0 / 1 / 0), 551 \mathrm{I}$ $(1 / 2 / 2)$, 553I $(0 / 1 / 0)$.

This species has frequently been found in the interstitial habitat of European running waters (Schwoerbel 1986). In Sicilian groundwaters, it was collected only in the Iblei Mountains.

\section{Discussion}

Ten of 11 Torrenticolid-species collected in 18 interstitial sampling sites were also found in superficial waters on Sicily. Only the new species $T$. hyporheica appears restricted to hyporheic habitat and has morphological specializations for subterranean living. Four other species, $T$. meridionalis, $T$. elliptica, $T$. algeriensis and $T$. crenobia, were collected in Sicilian surface waters but have not been sampled in groundwater (Table 4, Fig. 3). The most abundant species in interstitial habitats was T. lativalvata, followed by $T$. hyporheica and $T$. trinacriae.

As mentioned above, only $T$. hyporheica n.sp. is strictly hyporheobiontic. $T$. lativalvata is the most euryecious species inhabiting all types of Sicilian running waters and springs (Di Sabatino et al. 1992).
The species, along with $T$. trinacriae and $P$. rhynchota, can be considered as hyporheophilic. Torrenticola anomala, $T$. barsica, $T$. brevirostris and $T$. stadleri are typical of superficial waters and occur only occasionally in the hyporheic zone.

The high number of species of Torrenticola found in Sicilian groundwaters probably reflects the capability of these mites to invade the hyporheic zone opportunistically during periods of reduced flow. The mobility of deutonymphs and adults between interstitial and superficial waters is undoubtedly facilitated by their well sclerotized and flattened bodies (Angelier 1962, Cook 1969, Schwoerbel 1964, Petrova 1984).

The hydrogeological characteristics of Sicily also must play a key role by favouring the colonization of subterranean environment. The majority of Sicilian running waters are characterized by extreme instability (variation of flow, periods of drought, high temperature and salinity) and the continuity (spatial and temporal) of aquatic ecosystems depends upon access to groundwater.

The presence in superficial waters of Sicily and other Mediterranean regions of species such as $T$. andrei, $T$. madritensis, $T$. ungeri that are considered as strictly hyporheobiontic in the Alps and

Table 4. Presence and abundance of water mite species of the family Torrenticolidae in superficial and interstitial waters of Sicily. Tableau 4. Présence et abondance des espèces d'Hydracariens de la famille des Torrenticolidae dans les eaux superficielles et interstitielles de Sicile.

\begin{tabular}{|c|c|c|c|c|}
\hline \multirow[b]{2}{*}{ species } & \multicolumn{2}{|c|}{ superficial } & \multicolumn{2}{|c|}{ interstitial } \\
\hline & n & $\%$ & $\mathbf{n}$ & $\%$ \\
\hline T.algeriensis & 14 & 0.93 & 0 & - \\
\hline T.andrei & 4 & 0.27 & 5 & 3.13 \\
\hline T.anomala & 20 & 1.33 & 2 & 1.25 \\
\hline T.barsica & 403 & 26.8 & 6 & 3.75 \\
\hline T.brevirostris & 237 & 15.8 & 3 & 1.88 \\
\hline T.crenobia & 89 & 5.93 & 0 & - \\
\hline T.elliptica & 11 & 0.73 & 0 & - \\
\hline T.hyporheica & 1 & 0.07 & 20 & 12.5 \\
\hline T.lativalvata & 454 & 30.2 & 80 & 50.0 \\
\hline T.lusitanica cfr & 43 & 2.86 & 13 & 8.13 \\
\hline T.meridionalis & 8 & 0.53 & 0 & - \\
\hline T.stadleri & 88 & 5.86 & 4 & 2.5 \\
\hline T.trinacriae & 36 & 2.4 & 18 & 11.3 \\
\hline T.ungeri & 72 & 4.79 & 1 & 0.63 \\
\hline P.rhynchota & 22 & 1.46 & 8 & 5.0 \\
\hline
\end{tabular}


8pecies

Buperficlal $\square$ interstitial

T.algerlensis

T.andrel

T.anomala

T.barelca

T.brevirostris

T.crenobla

T.elliptlca

T.hyporhelca

T.laflvalvata

T.Iusitanica

T.meridionalls

T.trInacrlae

T.etadlerI

T.ungerl

P.rhynchota

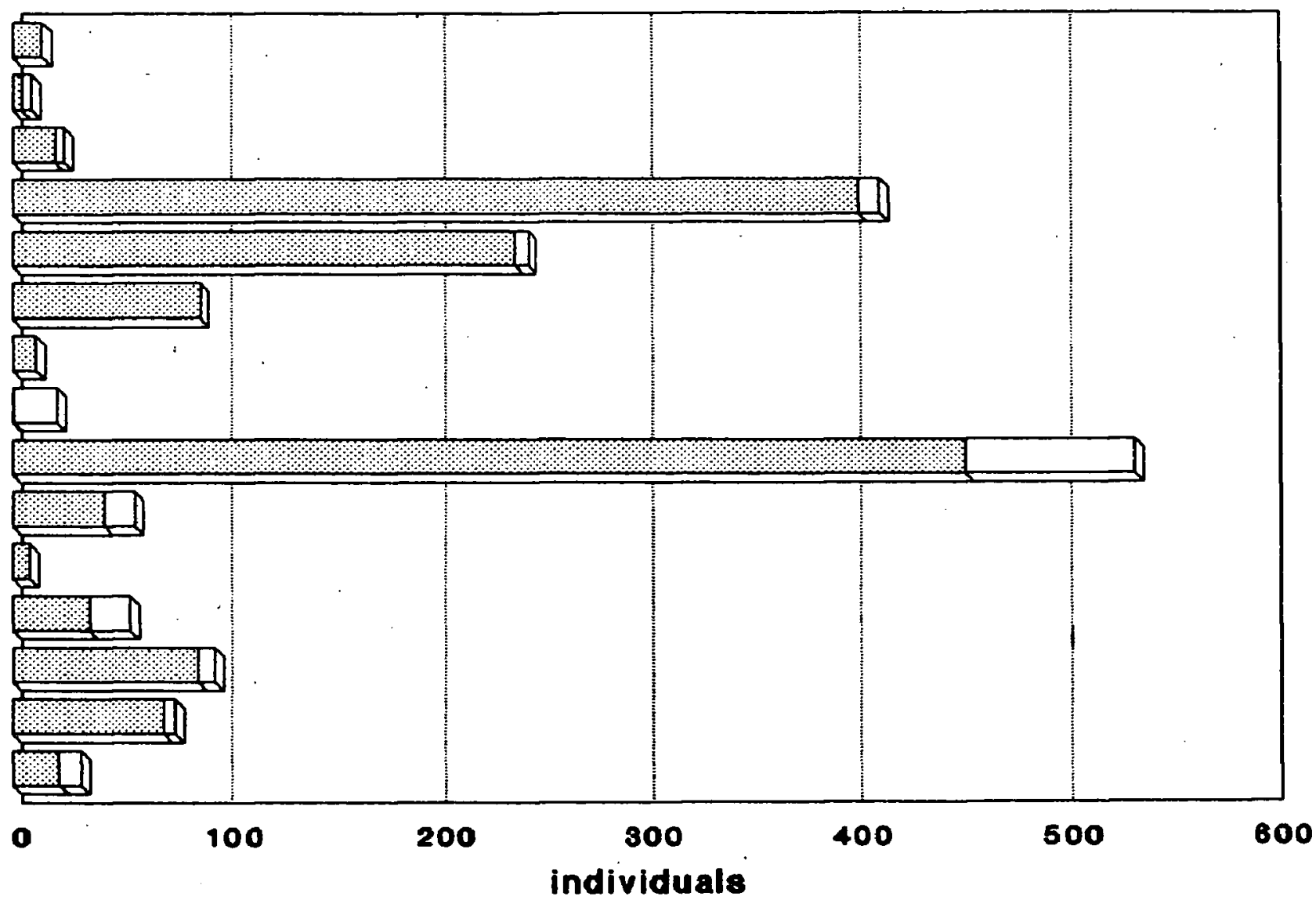

Fig. 3. Abundance of Torrenticolid-species in samples from superficial and interstitial waters of Sicily.

Fig. 3. Abondance des espèces de Torrenticolidae capturées dans les eaux superficielles et interstitielles de Sicile.

Central Europe (Schwoerbel 1962b, 1986) could be related to the diverse impacts of quaternary glaciations in these areas. Also ecological factors such as stream fluctuations and instability of aquatic ecosystems may reduce the effects of interspecific competition in the superficial habitat, and could explain increased vertical migration in streams in the Mediterranean region (Cicolani \& Di Sabatino 1990).

A preliminary comparison with Corsica, the only well investigated Mediterranean island (Angelier 1953, 1954, Santucci 1970, 1971, 1977, Viets 1954), shows strong faunistic differences. In Corsica, only four of the 13 reported species of Torrenticolidae are present in groundwaters (Table 5). Eight species are common to Corsica and Sicily. Four of these ( $T$. anomala, $T$. stadleri, $T$. brevirostris and $P$. rhynchota) are widely distributed in the Palearctic and the rest ( $T$. andrei, $T$. barsica, $T$. lativalvata and $T$. ungeri) inhabit the whole Mediterranean region and western-Europe.

The Sicilian fauna closely resembles that of southern Italy (Cicolani \& Di Sabatino 1990) with 9 species in common, 2 of which (to date) are limited to this area.
Table 5. Species of the family Torrenticolidae found in interstitial and superficial waters of Corsica and Sicily. $(-=$ absent ; $\mathrm{O}=$ sampled only in superficial waters $;+=$ sampled only in interstitial waters $; \theta=$ sampled in both habitats).

Tableau 5. Espèces de Torrenticolidae trouvées dans les eaux interstielles et superficielles de Corse et de Sicile. $(-=$ absence ; $\mathbf{O}=$ présence seulement dans les eaux superficielles $;+=$ présence seulement dans les eaux interstitielles ; $\Theta$ = présence dans les deux habitats).

\begin{tabular}{lcc}
\hline species & CORSICA & SICILY \\
\hline T.algeriensis & - & 0 \\
T.andrei & $\oplus$ & $\oplus$ \\
T.anomala & 0 & $\oplus$ \\
T.barsica & 0 & $\oplus$ \\
T.brevirostris & 0 & $\oplus$ \\
T.cavifrons & 0 & - \\
T.crenobia & - & 0 \\
T.elliptica & - & 0 \\
T.hyporheica & - & + \\
T.lativalvata & 0 & $\oplus$ \\
T.lusitanica cfr & - & $\oplus$ \\
T.minutirostris & 0 & - \\
T.meridionalis & - & 0 \\
T.ramigera & $\oplus$ & - \\
T.remy & 0 & - \\
T.stadleri & $\oplus$ & $\oplus$ \\
T.trinacriae & - & $\oplus$ \\
T.ungeri & 0 & $\oplus$ \\
P.rhynchota & $\oplus$ & $\oplus$ \\
\end{tabular}


Further research in the Mediterranean area will be needed to allow correct zoogeographic interpretation of these results.

\section{Acknowledgements}

This research was financially supported by a grant of M.U.R.S.T. "Ministero Ricerca Scientifica e Tecnologica " $(40 \%)$. We would like to thank Dr. Reinhard Gerecke who entrusted the study-material to us, and helped us with numerous suggestions in the preparation of the paper.

\section{References}

Angelier E. 1950. - Hydracariens phréaticoles de France. Genre Atractides. Bull. Mus. Hist. nat., Paris (2) 22, 1 : 85-91.

Angelier E. 1953. - Contribution à l'étude de la faune d'eau douce de Corse - Acariens psammiques (Hydrachnellae et Porohalacaridae). Vie Milieu 4 (3) : 505-539.

Angelier E. 1954. - Contribution à l'étude de la faune d'eau douce de Corse - Acariens (Hydrachnellae et Porohalacaridae) des eaux superficielles. Vie Milieu 5 : 74-148.

Angelier E. 1962. - Remarques sur la répartition de la faune dans le milieu interstitiel hyporhéique. Zool. Anz., 168 (7-10) : 351-356.

Bader C. 1983. - Zwei neue Wassermilben-Arten aus dem Interstitial des Mittelmeergebietes. Riv. Idrobiol., 22 (2-3) : 169-173.

Cicolani B. \& Di Sabatino A. 1990. - Recherches faunistiques et écologiques sur les Hydracariens de l'Apennin. Le genre Torrenticola Piersig (Acari, Actinedida, Torrenticolidae). Annls. Limnol., 26 (2-3) : 153-176.

Cook D. 1969. - The zoogeography of interstitial water mites. Proc. 2nd Int. Congr. Acarology 1967 : 81-87.

Delamare Deboutteville C. 1960. - La biologie des eaux souterraines littorales et continentales. Hermann, Paris. $740 \mathrm{p}$.

Di Sabatino A. \& Cicolani B. 1989. - Torrenticola crenobia n.sp. (Acari, Actinedida, Torrenticolidae) from a spring of the Calabrian Apennines, south Italy. Riv. Idrobiol., 28 (1-2) : 143-148.

Di Sabatino A. \& Cicolani B. 1990. - Torrenticola meridionalis $\mathrm{n} . \mathrm{sp}$., a new species of water mites from the Calabrian Apennines (South Italy). Lauterbornia 5 : 43-48.

Di Sabatino A. \& Cicolani B. 1992. - Torrenticola trinacriae una nuova specie di Acari acquatici (Acari, Actinedida, Torrenticolidae) raccolta in Sicilia. Animalia 17 (1990) : 189-195.
Di Sabatino A., Gerecke R. \& Cicolani B. 1992. - The family Torrenticolidae Piersig (Acari, Actinedida) in springs and running waters of Sicily. Arch. Hydrobiol. Suppl. 90 (2) : 253-282.

Gerecke R. 1991. - Taxonomische faunistische und ökologische Untersuchungen an Wassermilben (Acari Actinedida) aus Sizilien unter Berücksichtigung anderer aquatischer invertebraten. Lauterbornia 7 : 1-303.

Lundblad C.O. 1956. - Zur Kenntnis süd-und mitteleuropäischer Hydrachnellen. Ark. Zool. 10 (1) : 1-306.

Petrova A. 1984. - Origine et formation des Acariens stygobiontes. Hidrobiologya 22 : 3-24.

Santucci J. 1970. - Contribution à l'étude du comportement estival de quelques Hydracariens (Hydrachnellae) psammiques d'un torrent de Corse, Le Porto. Annls. Fac. Sci. Marseille. $44: 191-211$.

Santucci J. 1971. - Contribution à l'étude de la répartition des Hydracariens (Hydrachnellae) des eaux superficielles d'un torrent de Corse. Le Porto. Annls. Fac. Sci. Marseille 45 : 81-99.

Santucci J. 1977. - Contribution à l'étude des Acariens psammiques de Corse (Trombidiidae, Hydrachnellae, Porohalacaridae). Rapp. Comm. Int. Mer. Mèdi. 24 (9) : 83-85.

Schwoerbel J. 1961. - Hungarohydracarus subterraneus italicus nov ssp, die erste Süßwassermilbe (Hydrachnellae) aus dem hyporheischen Grundwasser Italiens. Memorie Ist. ital. Idrobiol. 13 : 115-124.

Schwoerbel J. 1962a. - Kawamuracarus vardaricola Viets 1943, eine für Italien neue Wassermilbe (Acari, Limnesiidae) aus dem hyporheischen Grundwasser des Tanaro. Memorie Mus. civ. Stor. nat. Verona $10: 37-40$.

Schwoerbel J. 1962b. - Subterrane Wassermilben (Hydrachnellae und Thrombiidae) aus den Alpen. Zool. Anz. 168 (7-10) : 292-300.

Schwoerbel J. 1964. - Die Bedeutung des Hyporheals fur die benthische Lebensgemeinschaft der Fliessgewässer. Verh. Internat. Ver. Limnol., $15: 215-226$.

Schwoerbel J. 1986. - Acari « Hydrachnellae » : 652-697. In L. Botosaneanu, ed., Stygofauna mundi (E. J. Brill, Leiden).

Szalay L. 1947. - Einige Atractides-Formen (Hydrachnellae) aus Unterirdischen Gewässern des Karpatenbeckens. Annls. hist. nat. Mus. Natn. hung. 40, 7 : 289-303.

Teschner D. 1988. - Porolohmannella fortipalpis n.sp. and other water mites from Italian rivers. Animalia $15: 72-77$.

Viets K. 1939. - Halacariden (Acari) aus süditalienischen Hölengewassern. Arch. Hydrobiol. $35: 4$ : 625-630.

Viets K. 1954. - Neue Wassermilben (Hydrachnellae, Acari) von Corsica. Zool. Anz. 152 (11-12) : 305-308. 